\title{
Reshaping of Shipping and Logistics in Smart, Green and Digital
}

\author{
Fausta Ari Barata \\ University of 17 Agustus 1945, Surabaya, Indonesia \\ fausta.untagsby@fab-enterprises.com
}

\begin{abstract}
The modern market has specific achievements as well as modern infrastructure. One of them is to build a smart port, environmentally friendly, and digitalization. Digitalization is part of industry 4.0, and both of them become a threat, but give opportunities to change the business and make a business model make a change. The international market has grown speedily sea transportation to become an important part on delivery goods from other countries. Sustainability sea transportation is done by providing easy access, affordability, safety, economist, reliability, infrastructure with the concept of environmentally friendly and friendly transportation service. Nowadays the maritime logistics is to become attention for stakeholders in the logistic sector. The evolution of maritime logistics is as a new discipline has produced greater change, from increasing ping ship, increasing customer request, the changing of a support role on supply chain, and logistic. The delivery with environmentally-friendly lead to use resources and energy to transport the people and good with a ship and special attention on decreasing resources and energy to preserving global environment and environmental pollutants resulted by ship.
\end{abstract}

Keywords

Reshaping; shipping; logistics; smart; green; digital

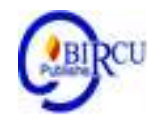

\section{Introduction}

The 4.0 industrial revolution has an impact on business behavior in Indonesia. The phenomenon of the 4.0 industrial revolution is the changing lifestyles of society and the emergence of the phenomenon of online shopping has eroded the modern retail market, so that the influence is slowing growth in modern retailing. In the era 4.0 industrial revolution, the most popular technology in business is information technology (IT) with digital technology and internet will be the basis of revolutionary change in all industries. Information technology is essential in creating a tightly integrated value chain and delivering high quality service, so as to enable companies to always innovate. Technology and innovations is very important to the retailing industry as it plays a significant role in helping retailers to improve their business and to provide the best service for customers. (Kusumadewi and Karyono)

The digital era drives the development of technology in the manufacturing industry sector in Indonesia. Domestic investment is expected to increase the manufacturing industry sector as well as to encourage the development of technology to increase productivity and competitiveness. (Pramusinto and Daerobi, 2020) The future modern market is not only exchange good between two parties, but also cooperation partnership agreement which interdependent in their business-critical and done in geography, time zona, large limited (Kupriyanovskaya, 2018). The modern market has specific achievements as well as modern infrastructure. One of them is building a smart port. The role of a smart port is as one industrial intermediary each other (Li, Zhang, Lin, \& Huang, 2019). 
Industrial 4.0 supports raising smart industries which, are set on a series of technology and organization. The development has achieved industrial revolution 4.0 era colored with implementation artificial intelligence, supercomputer, big data and digital innovation which can as important support to navigate product flow, component, material and make data available resulted, so human resources management and decision making divided into stage cycle of industrial lives have increased (Kristoffersen, Blomsma, Mikalef, \& Li, 2020).

Industrial 4.0 is an integration of Cyber-Physical System (CPS) and Internet of Things and Services (IoT and IoS). The industrial process included manufacture, logistic, etc. Industrial revolution 4.0 with a sign with the implementation of smart industry refers to increasing automation, human to machine communication, artificial intelligence, and digital technology suitability development. industrial revolution 4.0 as transformation effort toward improvement process with line integration production with cyber, where production process with online through internet connection as the main cantilever (Olessków-Szłapka, Wojciechowski, Domański, \& Pawłowski, 2019).

Digitalization is part of industrial 4.0 and both of them as threat, but give an opportunities to change business and can all business model make a change. Although the company realized need digitalization, a lot of unbelieve how started the digital transformation (von Leipzig et al., 2017). Based on searching in Google Trends to correct the potency in logistic aspect 4.0 Indonesia as development country and Jerman as country origin in term industrial 4.0 get score 100 present high popularity from specific keyword, and score 0 present there is no data in keyword this word (Kostrzewski, Kosacka-Olejnik, \& WernerLewandowska, 2019), The result of searching:

a. Interest on time term

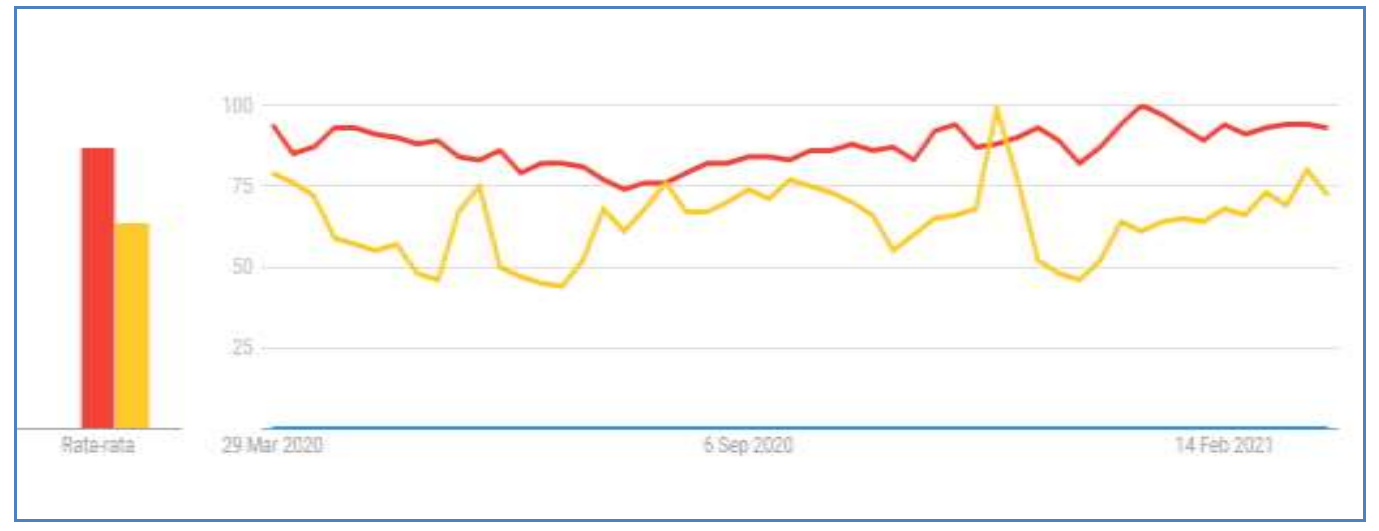

b. Interest on area term

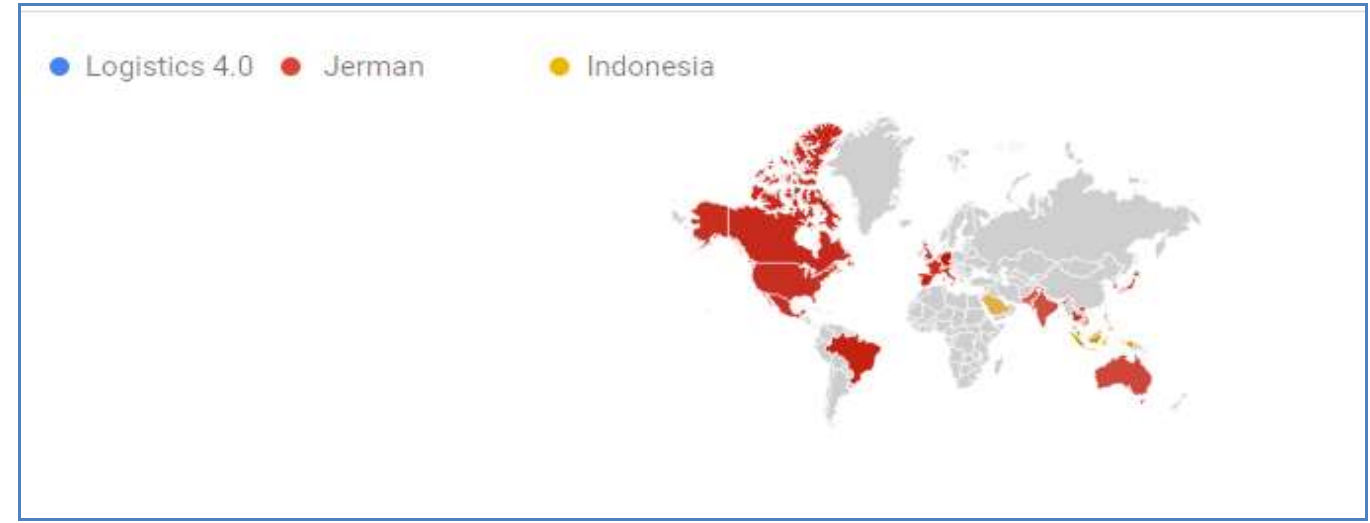

Figure 1.the influence searching on Google Trends in case keyword "Logistik 4.0": (a) interest on area term, $(b)$ interest on time.

https://trends.google.pl/trends/explore? $q=$ Logistics\%204.0,\%2Fm\%2F04306rv,Indonesia 
The strategy initiative industrial 4.0 comes from Germany that is industrial manufacture transformation through digitalization and exploits the potential new technology. Germany is very interested in industrial 4.0 that is part of the policy development plan namely High-Tech Strategy 2020. Germany's policy is purposed to maintain status as frontline manufacture (Rojko, 2017). Germany has many challenges which must be solved by a firm, but the procedure implementation industrial 4.0 has high potential to secure the future of industrial manufacture. In industrial revolution 4.0 especially creating smart environment in a production system with main priority are change, operational manufacture, and information technology (Bae, 2017).

The development of sea transportation has become the main transportation in the global market. International market growth rapidly, sea transportation become important on good delivery between country. The sustainability of sea transportation is done with available access easily, affordability, economic, reliability, infrastructure environmental friendly and transportation with friendly service (Jović, Tijan, Žgaljić, \& Aksentijević, 2020).

Nowadays, maritime logistics is becoming an interested stakeholder of the logistic sector. The evolution of logistic maritime is a new discipline that resulted in a high change from increasing ping ship. And customer requests also develop the role of support change in supply chain context and logistics. The function of the port has developed from the traditional process that facilitates the activity of loading and unloading and logistic chain massively as part of global distribution channel. One of the developments of performant and service quality of maritime logistics is increasing port efficiency, such as cost control of sea transportation. Delivering must efficient and sustainable on increasing global economic group, but focus on environmental protection, cost-effectivity, and global transportation available which is safe and energy-efficient. (Amin, Mulyati, Anggraini, \& Kusumastanto, 2021).

Application of container delivery of national shipping with Booking Online system, it will develop directly to smart port with many advantages. The advantages are the transparency of cost, schedule, service, the user of sea freight get all information need when they booking, receive reservation when booking process, as well as certainty, and transaction process faster. In terms of fuel usage, this application also set content to enforce the sulfur on international shipping fuel (enforce the sulfur is not more than $0,5 \% \mathrm{~m} / \mathrm{m}$ ) and ship operated in the emission control area (enforce sulfur in not more than $0,1 \% \mathrm{~m} / \mathrm{m}$ ). this requirement will become object port control officer inspection for ships sailing at international water (Raza, Sabbarudin, \& Komala, 2020).

The country applies industrial 4.0, will face a challenge, such as change the demography and social aspect, limitation of resources, applies technology environmental friendly (Ricardianto, Nasution, Naiborhu, \& Triantoro, 2020). Digital logistic integration, lack manual work drastically, and open a new way are to optimization process of logistic and transportation route with real-time to reaction dynamic in unforeseen circumstances. The impact, the integration of new information technology and communication offer the greater potential to increasing cost effectivity in logistic and make a possible new business model based on digital. Digital technology is help on human decision making or independent decision making which following the norm and ethical consideration applied in an environment (Lobschat et al., 2021).

According to Kayikci (2018), the concept of digital logistic is allow transpiration all the time from supplier to customer or transpiration supply chain. Beside, logistic must greater vision to fulfill the requirement of industrial 4.0 sustainability on using right technology and increasing vertical and horizontal integration between partner supply chain. 
Logistic digitalization is started with transformational digital means there is a change in business process which increasing the values are faster, better and cheaper. Optimization of three values digitalization is needed the involvement of many parties or stakeholders. (Raza et al., 2020). Involving of stakeholder is unlimited attachment to a platform, but need integration ecosystem which give adding value to all stakeholder.

\section{Research Methods}

The design of the research is a literature review. According to Daniel and Warsiah, (2009) literature means the research done by a researcher with collected books, magazines related to the problem, and the purpose of the research. The technique did to reveal many theories relevant to the problem face or study as a reference on a discussion of the result of the research. Library research is a series of research that concerning library data collection methods or studies with research objects excavated through much information in the library (such as books, encyclopedias, scientific journals, magazines, newspapers, and documents).

The data used in this study is secondary data. Secondary data is the source of the data indirectly give data to data collection, such as through other people or via documents (Sugiyono, 2015). The data in this research is a source from books, national and international scientific journals. This study did know reshaping of shipping and logistics in smart, green, and digital through a literature review which finds the related source and make a conclusion suitable for research purposes. The criteria of publication or source used are suitable with the tame of the research has done.

\section{Results and Discussion}

\subsection{Digital Logistic}

Digitalization is making information and available communication everywhere, anywhere, all the context, and all the users who use an application and all the access. (Kayikci, 2018). According to Raza et al., (2020) Digitalization is increasing available data digital which possible by developing, creating, transferring saving, and analyzing data digitally, have the potential to arrange, shape, and influence the contemporary era.

Digitalizations are all the process of planning, sources, made, delivery, taking which will increase the logistic process, optimization work flow, and reduced waiting time. It is a figure of a sustainable digital logistic ecosystem, which present digitalization has the effect of logistic from dimension perspective of economic, environmental, and social sustainability:

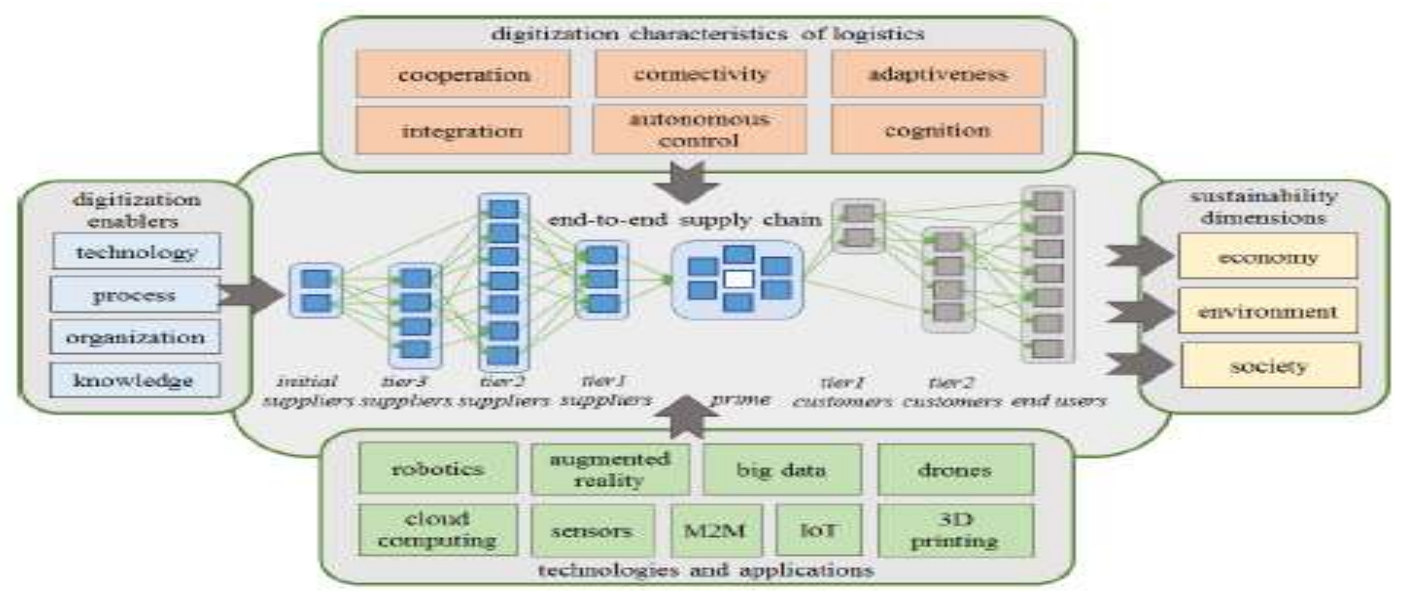

Figure 1. Sustainable digital logistic ecosystem (Kayikci, 2018) 
From the figure above, explain the sustainable dimension which reflects: 1) economist: affordability system which operates with efficient, offer a collaborative solution and combination of a mode of transportation selected and support local economies. 2) Environment: reduce emission gas greenhouse, pollution, and waste, minimalize consumption non-renewable of source energy, and using reuse technology and recycling component. 3) Social: Individuals access basic needs/community to fulfill with safety and support good lifestyle, and equality within and between generation.

Further, characteristic of digitalization on logistic are: 1) Cooperation: cooperation act (such as together where house and transportation capacity) through digitalization has potential to increasing efficiency and logistic industrial reliability, it creating special need between organizations which information exchange and data integration and architecture to support cluster logistic virtual. 2) Connectivity refers to technology's ability to act as an interface to the resources of another digital network, or to receive a connection from other resources. 3) Adaptiveness: Digitalization refers to an open dynamic adaptive system with the characteristic fact of components and relationships can change along with time and can be influenced by the external limit event. 4) integration refers to the ability of the system to connecting, integrating, monetize, ban sharing data, device, system, and process soon or in real-time on the digital economy. 5) Autonomous Control: Digitalization makes decision making which decentralization and autonomous, 6) cognition: The function of logistic undergoing fundamental change with technology development such as artificial intelligence (AI), robot, drone to control goods movement domestic and international.

\subsection{Reshaping of Shipping in Smart, Green and Digital}

The basic internal logistic system is a supporting service that available to handling and transportation the material to the superior manufacturing process, more significant, and 0 scores. Therefore, it is no doubt which can bring change in the manufacturer environment (Lambrou, Watanabe, \& Iida, 2019). At firm manufacture, Intelligent Manufacturing Systems (IMS) is a production system issued flexible on adaptation with a new product, therefore, the logistic system must be able to adaptations speedily and smoothly in the change. The internal logistic system can offset evolution speedily which happened manufacturing system domain, it needs each development. The specification needs Intelligent Logistics Solution are: adaptation ability, changeability, flexibility, independent organization, reconfiguration speed, single element autonomy behavior, smart decision making, etc. (Gregor, Krajčovič, \& Więcek, 2017).

This specification can fulfill by utilizing elements are movement robotic system; handle robotic; element and smart subsystem; IoT (Internet of Things). The basic of Smart Connected Logistics system is Smart Connected Products system set through a cloud, while the basic solution of cloud is also accessed the information from the data source another factory, such as planning, and control production. A system, external logistics, etc. (Gregor et al., 2017).

Delivery environment friendly refers to using resources and energy to transport people and goods with a ship and special attention on reduction of resources and energy to preserve the global environment and environment pollutant resulted by ship. Ship environmental friendly has faction as the main instrument in transport an operational sector which enable environmental friendly. Ship environmental friendly is technology development related with fuel economy and alternative fuel (Lee \& Nam, 2017). 


\section{Conclusion}

Digitalization is part of industrial 4.0 both of them threatening, but give an opportunity to change the business and can make business model did change. Digitalization makes available information and communication everywhere, anywhere, all the context, all the users who use this application, and all the access. Digitalization is increasing available digital data possible by development on creating, transferring, saving, analyzing digital data, have potential to arrange, shape, and influencing contemporary.

Manufacture firm of Intelligent Manufacturing Systems (IMS) on production system sued flexible on adaptation with new product. Therefore the logistic system must be able to adaptation speedily and smooth to this change. The basic Smart Connected Logistics system is the Smart Connected Products system is set through a cloud, while, the solution-based cloud is also accessed the information from the data source with other factories, such as planning and controlling production system, external logistic, and etc. Delivery environmental friendly refers to using resources and energy to transport people and goods with a ship and special attention on reduction resources and energy to conserve the global environment and environment pollutant resulted by ship.

\section{References}

Amin, C., Mulyati, H., Anggraini, E., \& Kusumastanto, T. (2021). Impact of maritime logistics on archipelagic economic development in eastern Indonesia. Asian Journal of Shipping and Logistics, (xxxx). https://doi.org/10.1016/j.ajsl.2021.01.004

Bae, H. S. (2017). Empirical Relationships of Perceived Environmental Uncertainty, Supply Chain Collaboration and Operational Performance: Analyses of Direct, Indirect and Total Effects. Asian Journal of Shipping and Logistics, 33(4), 263-272. https://doi.org/10.1016/j.ajsl.2017.12.010

Daniel dan Warsiah. (2009). Metode Penulisan Karya Ilmiah. Bandung: UPI.

Gregor, T., Krajčovič, M., \& Więcek, D. (2017). Smart Connected Logistics. Procedia Engineering, 192, 265-270. https://doi.org/10.1016/j.proeng.2017.06.046

Jović, M., Tijan, E., Žgaljić, D., \& Aksentijević, S. (2020). Improving maritime transport sustainability using blockchain-based information exchange. Sustainability (Switzerland), 12(21), 1-19. https://doi.org/10.3390/su12218866

Kayikci, Y. (2018). Sustainability impact of digitization in logistics. Procedia Manufacturing, 21, 782-789. https://doi.org/https://doi.org/10.1016/j.promfg.2018.02.184

Kostrzewski, M., Kosacka-Olejnik, M., \& Werner-Lewandowska, K. (2019). Assessment of innovativeness level for chosen solutions related to Logistics 4.0. Procedia Manufacturing, 38(2019), 621-628. https://doi.org/10.1016/j.promfg.2020.01.080

Kristoffersen, E., Blomsma, F., Mikalef, P., \& Li, J. (2020). The smart circular economy: A digital-enabled circular strategies framework for manufacturing companies. Journal of Business Research, 120(August), 241-261. https://doi.org/10.1016/j.jbusres.2020.07.044

Kupriyanovskaya, et. al. (2018). Smart container, smart port, BIM, Internet Things and blockchain in the digital system of world trade. nt. J. Open Inf. Technol., 6(3), 49-94.

Kusumadewi, R and Karyono, O. (2019). Impact of Service Quality and Service Innovations on Competitive Advantage in Retailing. Budapest International Research and Critics Institute-Journal (BIRCI-Journal). P. 366-374. 
Lambrou, M., Watanabe, D., \& Iida, J. (2019). Shipping digitalization management: conceptualization, typology and antecedents. Journal of Shipping and Trade, 4(1). https://doi.org/10.1186/s41072-019-0052-7

Lee, T., \& Nam, H. (2017). A Study on Green Shipping in Major Countries: In the View of Shipyards, Shipping Companies, Ports, and Policies. Asian Journal of Shipping and Logistics, 33(4), 253-262. https://doi.org/10.1016/j.ajs1.2017.12.009

Li, Y., Zhang, X., Lin, K., \& Huang, Q. (2019). The analysis of a simulation of a Port-city green cooperative development, based on system dynamics: A case study of Shanghai Port, China. Sustainability (Switzerland), 11(21). https://doi.org/10.3390/su11215948

Lobschat, L., Mueller, B., Eggers, F., Brandimarte, L., Diefenbach, S., Kroschke, M., \& Wirtz, J. (2021). Corporate digital responsibility. Journal of Business Research, 122(July 2018), 875-888. https://doi.org/10.1016/j.jbusres.2019.10.006

Olessków-Szłapka, J., Wojciechowski, H., Domański, R., \& Pawłowski, G. (2019). Logistics 4.0 maturity levels assessed based on GDM (grey decision model) and artificial intelligence in logistics 4.0 -trends and future perspective. Procedia Manufacturing, 39(2019), 1734-1742. https://doi.org/10.1016/j.promfg.2020.01.266

Pramusinto,N and Daerobi, A. (2020). Labor Absorption of the Manufacturing Industry Sector in Indonesia. Budapest International Research and Critics Institute-Journal (BIRCI-Journal). P. 549-561.

Raza, E., Sabbarudin, L. O., \& Komala, A. L. (2020). Manfaat dan Dampak Digitalisasi Logistik di Era Industri 4.0. Jurnal Logistik Indonesia, 4(1), 49-63.

Ricardianto, P., Nasution, S., Naiborhu, M. A., \& Triantoro, W. (2020). Peluang dan Tantangan Sumber Daya Manusia dalam Penyelenggaraan Pelabuhan Cerdas (Smart Port) Nasional di Masa Revolusi Industri 4.0. Warta Penelitian Perhubungan, 32(1), 59-66. https://doi.org/10.25104/warlit.v32i1.1524

Rojko, A. (2017). Industry 4.0 concept: Background and overview. International Journal of Interactive Mobile Technologies, 11(5), 77-90. https://doi.org/10.3991/ijim.v11i5.7072

Sugiyono. (2015). Metode Penelitian Kuantitatif Kualitatif R \& D. Bandung: Alfabeta.

von Leipzig, T., Gamp, M., Manz, D., Schöttle, K., Ohlhausen, P., Oosthuizen, G., ... von Leipzig, K. (2017). Initialising Customer-orientated Digital Transformation in Enterprises. Procedia Manufacturing, 8(October 2016), 517-524. https://doi.org/10.1016/j.promfg.2017.02.066 